\title{
Insights into the Protective Effects of Thymoquinone against Toxicities Induced by Chemotherapeutic Agents
}

\author{
Juveriya Farooq ${ }^{1}{ }^{(\mathbb{C},}$, Rokeya Sultana ${ }^{2, *}$, Tahreen Taj ${ }^{1}$, Syed Mohammed Basheeruddin Asdaq ${ }^{3, *}(\mathbb{D}$, \\ Abdulkhaliq J. Alsalman ${ }^{4}$, Mohammed Al Mohaini ${ }^{5,6}{ }^{\oplus}$, Maitham A. Al Hawaj ${ }^{7}$, Mehnaz Kamal ${ }^{8}(\mathbb{D}$, \\ Saad Alghamdi $\left.{ }^{9} \mathbb{(}\right)$, Mohd. Imran ${ }^{10}\left(\mathbb{D}\right.$, Haleema Shahin ${ }^{1}\left(\mathbb{D}\right.$ and Ruheena Tabassum ${ }^{1} \mathbb{C}$
}

Citation: Farooq, J.; Sultana, R.; Taj,

T.; Asdaq, S.M.B.; Alsalman, A.J.;

Mohaini, M.A.; Al Hawaj, M.A.;

Kamal, M.; Alghamdi, S.; Imran, M.; et al. Insights into the Protective Effects of Thymoquinone against

Toxicities Induced by

Chemotherapeutic Agents. Molecules 2022, 27, 226. https://doi.org/ $10.3390 /$ molecules 27010226

Academic Editors: Rosanna Maccari and Rosaria Ottana

Received: 25 November 2021

Accepted: 28 December 2021

Published: 30 December 2021

Publisher's Note: MDPI stays neutral with regard to jurisdictional claims in published maps and institutional affiliations.

Copyright: (C) 2021 by the authors. Licensee MDPI, Basel, Switzerland. This article is an open access article distributed under the terms and conditions of the Creative Commons Attribution (CC BY) license (https:// creativecommons.org/licenses/by/ $4.0 /)$.
1 Department of Pharmacology, Yenepoya Pharmacy College and Research Centre, Yenepoya (Deemed to be University), Mangalore 575018, India; juveriyafarooq@gmail.com (J.F.); tahreentaj6414@gmail.com (T.T.); shahin@yenepoya.edu.in (H.S.); ruheenat@gmail.com (R.T.)

2 Department of Pharmacognosy, Yenepoya Pharmacy College and Research Centre, Yenepoya (Deemed to be University), Mangalore 575018, India

3 Department of Pharmacy Practice, College of Pharmacy, AlMaarefa University, Riyadh 13713, Saudi Arabia

4 Department of Clinical Pharmacy, Faculty of Pharmacy, Northern Border University, Arar 91911, Saudi Arabia; KALIQS@gmail.com

5 Basic Sciences Department, College of Applied Medical Sciences, King Saud Bin Abdulaziz University for Health Sciences, Riyadh 31982, Saudi Arabia; mohainim@ksau-hs.edu.sa

6 King Abdullah International Medical Research Center, Thuwal 31982, Saudi Arabia

7 Department of Pharmacy Practice, College of Clinical Pharmacy, King Faisal University, Al-Ahsa 31982, Saudi Arabia; hawaj@kfu.edu.sa

8 Department of Pharmaceutical Chemistry, College of Pharmacy, Prince Sattam Bin Abdulaziz University, Al-Kharj 11942, Saudi Arabia; mailtomehnaz@gmail.com

9 Laboratory Medicine Department, Faculty of Applied Medical Sciences, Umm Al-Qura University, Makkah 21955, Saudi Arabia; Ssalghamdi@uqu.edu.sa

10 Department of Pharmaceutical Chemistry, Faculty of Pharmacy, Northern Border University, Arar 91911, Saudi Arabia; imran.pchem@gmail.com

* Correspondence: rokeya009ster@gmail.com or drrokeyasultana@yenepoya.edu.in (R.S.); sasdaq@gmail.com or sasdag@mcst.edu.sa (S.M.B.A.)

Abstract: The drugs used to treat cancer not only kill fast-growing cancer cells, but also kill or slow the growth of healthy cells, causing systemic toxicities that lead to altered functioning of normal cells. Most chemotherapeutic agents have serious toxicities associated with their use, necessitating extreme caution and attention. There is a growing interest in herbal remedies because of their pharmacological activities, minimal side effects, and low cost. Thymoquinone, a major component of the volatile oil of Nigella sativa Linn, also known as black cumin or black seeds, is commonly used in Middle Eastern countries as a condiment. It is also utilized for medicinal purposes and possesses antidiabetic, anticancer, anti-inflammatory, hepatoprotective, anti-microbial, immunomodulatory, and antioxidant properties. This review attempts to compile the published literature demonstrating thymoquinone's protective effect against chemotherapeutic drug-induced toxicities.

Keywords: thymoquinone; chemotherapy-induced toxicity; antioxidant; phytoconstituents; organ protection

\section{Introduction}

The National Cancer Institute defines cancer as a disease in which there is uncontrollable growth of the cell, spreading to other parts of the body [1]. According to the Global Burden of Disease, total cancer was found to be the second-most cause of deaths globally (9.36 to 10.6 million deaths) in 2019 [2]. Table 1 represents different types of cancer and total deaths from cancer in India [3]. Risk factors are classified as intrinsic risk factors and non-intrinsic risk factors. Intrinsic risk factors occur mostly because of errors in DNA replication and are always unmodifiable. Non-intrinsic risk factors are again divided into 
two types that are partially modifiable endogenous risk factors and modifiable exogenous risk factors. Partially modifiable endogenous risk factors include age, genetic susceptibility, DNA repair machinery, hormones, growth factors, and inflammation. Modifiable exogenous risk factors include exposure to radiation, chemical carcinogens (asbestos, Azodyes etc.), tumor causing viruses (Hepatitis $C$ virus, Human papilloma virus, Epstein-Barr virus etc.), as well as lifestyle features including smoking, drinking alcohol, lack of exercise, imbalance in nutrition etc., [4]. All these risk factors contribute to the development of cancerous cells leading to disease progression, thus resulting in the presentation of multiple symptoms further deteriorating the quality of life [5]. Cancer mortality can be reduced if it is detected and treated at its earliest appearance [6]. It can also be prevented by adapting healthy lifestyle factors such as eliminating the use of tobacco, keeping a strong body mass index (BMI) and by limiting alcohol consumption [7]. Treatment approaches include surgery, radiotherapy, chemotherapy, hormone therapy, and molecular targeted therapy used alone or in combination with other therapies [8].

Table 1. Cancer types and total deaths from cancer in India, in 2019.

\begin{tabular}{ccc}
\hline Sl. No. & Types of Cancer & Total Deaths in Percentage \\
\hline 1 & Lung cancer & $0.95 \%$ \\
2 & Breast cancer & $0.89 \%$ \\
3 & Stomach cancer & $0.87 \%$ \\
4 & Colorectal cancer & $0.84 \%$ \\
5 & Lip and oral cavity cancer & $0.70 \%$ \\
6 & Other malignant neoplasm & $0.61 \%$ \\
7 & Cervical cancer & $0.48 \%$ \\
8 & Esophageal cancer & $0.41 \%$ \\
9 & Leukemia & $0.36 \%$ \\
10 & Pancreatic cancer & $0.36 \%$ \\
11 & Prostate cancer & $0.34 \%$ \\
13 & Liver cancer & $0.33 \%$ \\
14 & Larynx cancer & $0.32 \%$ \\
15 & Ovarian cancer & $0.24 \%$ \\
\hline
\end{tabular}

Chemotherapy involves the systemic application of chemicals or drugs to kill cancer cells. Different types of chemotherapeutic drugs are used to treat cancer and are classified based on their mechanism of action. Common drugs include: (1) alkylating agents which work by damaging the DNA and thus prevent the cell from reproducing. Examples include cisplatin, ifosfamide, chlorambucil, carmustine, melphalan, etc.; (2) antimetabolites which act as a substitute for the normal building blocks of RNA and DNA by interfering with their metabolism. Examples include: 5-fluorouracil, capecitabine, 6-mercaptopurine, cytarabine, gemcitabine, methotrexate, etc.; (3) antitumor antibiotics that act by binding with DNA and prevent the synthesis of enzymes involved in DNA replication. Examples include doxorubicin, daunorubicin, epirubicin, bleomycin etc.; (4) topoisomerase inhibitors also known as plant alkaloids, which work by inhibiting topoisomerases enzymes (I \& II) involved in separating the strands of DNA during replication and transcription process. Examples include: irinotecan, topotecan, etoposide, teniposide, etc.; (5) mitotic inhibitors which are plant alkaloids responsible for inhibiting mitosis and cell division by disrupting microtubules essential for cell reproduction. Examples include docetaxel, paclitaxel, vincristine, vinblastine etc.; (6) corticosteroids which bind to cytoplasmic receptors thus inhibiting DNA synthesis and relieve the side effects caused due to other chemotherapeutic agents. Examples include prednisone, methylprednisolone, and dexamethasone [9].

However, the disadvantage of using chemotherapy is that it affects the healthy cells leading to altered functioning of normal cells. Most of the chemotherapeutic agents have serious toxicities associated with their use. Some of the common toxicities involved are nephrotoxicity, cardiotoxicity, hepatotoxicity, pulmonary toxicity, hematological, gastroin- 
testinal, skin and hair follicle toxicity, nervous system toxicity, local toxicity, urinary tract toxicity, gonadal toxicity, etc. [10]. Techniques for reducing chemotherapy-induced toxicity include reductions in dosage, the usage of alternate medications, growth factors, and cytoprotective agents [11]. If the use of chemotherapy causes life threatening toxicity, it is essential to remove the offending agent making the therapy incomplete. For this reason, studies are being focused on use of safer therapeutic compounds.

Phytochemicals are a class of naturally occurring compounds that are used as medicinal agents in the treatment of a variety of diseases [12]. This paper provides an overview of thymoquinone's protective function in lowering chemotherapeutic drug-induced toxicities. An extensive literature survey was conducted using common databases such as PubMed, Scopus, Google Scholar, Science Direct, Springer link, research gate, SAGE journals and other related published manuscripts.

\section{Phytochemicals}

Phytochemicals are biologically active plant-derived compounds which have been extracted from various sources including fruits for example, apples and grapes, vegetables such as onion and broccoli, spices including turmeric, herbal teas like green tea etc. [13,14]. Alkaloids, glycosides, flavanoids, phenolics, saponins, tannins, and terpenes are some of the phytochemical chemicals found in plants [15]. The majority of them have a wide range of pharmacological actions and are well tolerated [16]. Phytochemicals have been shown to decrease risk of a wide variety of illnesses such as autoimmune disease [17], cardiovascular disease [18], neuro-degenerative disorder [19], cancer [20], aging [21], obesity [22] and many more. As chemotherapy is associated with adverse effects, the addition of some phytochemicals to the regimen has the potential to improve their efficacy and alleviate their toxicities. The mechanism involved in reducing chemotherapeutic drug-induced toxicities is likely due to the anti-oxidative and anti-inflammatory properties. These constituents effectively scavenge reactive oxygen species, preventing oxidative stress and attenuating inflammation [23].

\section{Thymoquinone (TQ)}

Thymoquinone (2-Isopropl-5-methyl benzo-1,4-quinone) (Figure 1) [24] is an active component of the volatile oil of Nigella sativa (black seeds) (Figure 2) [25-27]. Other than the Ranunculaceae family (N. sativa), this compound has been detected in other families such as Lamiaceae (Modernadidyma, M. menthifolia, etc.), Asteraceae (Eupatorium cannabinum), and Cupressaceae (Juniperus communis) [28]. It has a broad range of pharmacological actions involving anti-oxidative, anti-inflammatory, immunomodulatory, anti-cancer, anti-microbial, hepatoprotective, hypoglycemic and antidiabetic, gastroprotective, neuroprotective, cardioprotective, nephroprotective, hypolipidemic, and anti-histaminic effects. It also showed a protective effect on reproductive system, respiratory system, and bone related disorders [29]. TQ is generally safe to use but toxicity has been observed at higher doses $\left(\mathrm{LD}_{50}, 2.5 \mathrm{~g} / \mathrm{kg}\right)$. In a study conducted by Abukhader, Wistar Albino rats administered with $30 \mathrm{mg} / \mathrm{kg}$ and $40 \mathrm{mg} / \mathrm{kg}$ of TQ showed signs of toxicity such as lethargy, abdominal swelling, piloerection, irritability, and weight loss. It was found that $22.5 \mathrm{mg} / \mathrm{kg}$ and $15 \mathrm{mg} / \mathrm{kg}$ are the maximum tolerated doses (MTD) through the intraperitoneal route (I.P) in male rats and female rats, respectively. When administered orally at doses of $500 \mathrm{mg} / \mathrm{kg}$ and $300 \mathrm{mg} / \mathrm{kg}$, toxicity signs like dyspnea, abdominal distension, weight loss, diarrhea, and hypoactivity were observed. The MTD through oral route (P.O) for both male as well as female rats were reported as $250 \mathrm{mg} / \mathrm{kg}$. MTD is the highest safe dose that can be administered without showing signs of toxicity [30]. 


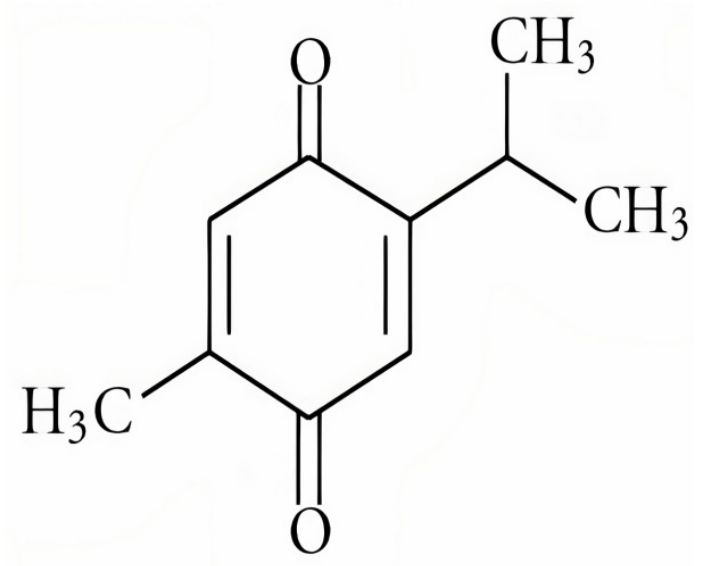

Figure 1. The chemical structure of thymoquinone [24].

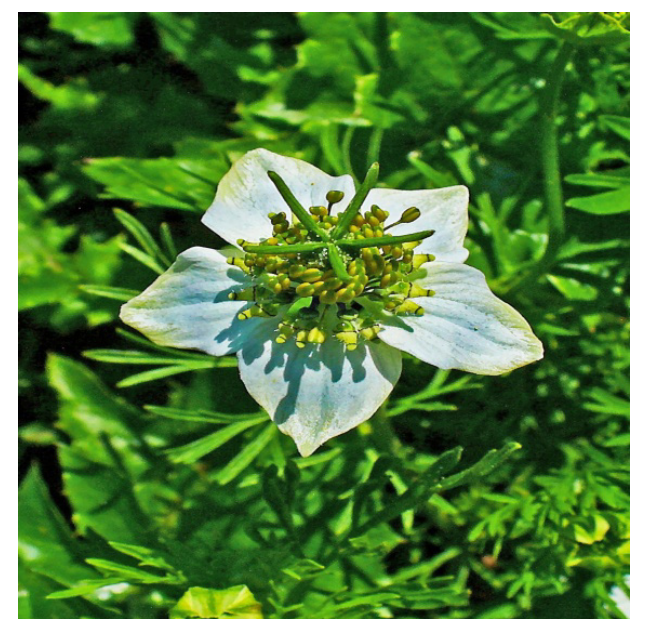

(a)

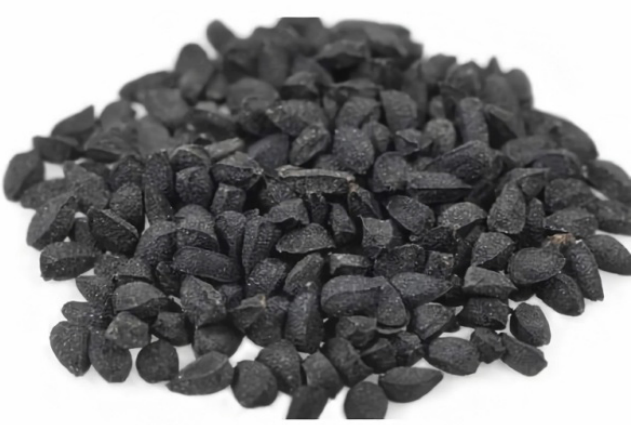

(b)

Figure 2. Nigella sativa (a)flower (b) seeds [26,27].

\subsection{Role of Thymoquinone in Cancer}

There are many preclinical studies (both in vivo and in vitro) which demonstrate the effect of TQ, given alone or in combination with other chemotherapeutic agents. It is known to target various processes of the cancer model such as cell cycle progression, proliferation, apoptosis, angiogenesis, migration, invasion, and metastasis of tumors. It also prevents oxidative damage and inhibits inflammatory responses [29]. TQ showed therapeutic efficacy against a wide range of cancer including ovarian cancer [31,32], breast cancer [33,34], pancreatic cancer [35], lung cancer [36,37], fibrosarcoma [38], neuroblastoma [39], osteosarcoma [40], myeloma [41], oral cancer [42], colon cancer [43,44], prostate cancer [45], squamous cell carcinoma [46], gastric cancer [47], leukemia [48], cervical cancer [49], liver cancer [50,51], and skin cancer [52]. In addition to its chemotherapeutic effects, it also diminishes the toxic side effects caused by chemotherapeutic agents.

\subsection{Effect of TQ against ChemotherapyInduced Organ Toxicity}

Toxicity is a major concern for chemotherapeutic drugs. Some of the most widely used chemotherapeutic drugs possess organ toxicity which leads to further economic burden and decreased quality of life. Isolated phytoconstituents are equipotent to synthetic analogues and have lesser side effects. Table 2 shows the findings of previous studies of thymoquinone in reducing toxicity of chemotherapeutic agents. 
Table 2. Effect of thymoquinone against chemotherapy-induced toxicities.

\begin{tabular}{|c|c|c|c|}
\hline Drug Induced Toxicity & Experimental Model & TQ Dose & Effect of TQ \\
\hline $\begin{array}{l}\text { Doxorubicin induced } \\
\text { cardiotoxicity }[23,53]\end{array}$ & Swiss albino mice/adult male albino rats. & $\begin{array}{l}10 \mathrm{mg} / \mathrm{kg} \text { p.o and } \\
20 \mathrm{mg} / \mathrm{kg} \text {, body weight p.o in swiss } \\
\text { albino mice. } \\
10 \mathrm{mg} / \mathrm{kg} / \text { day i.p in albino rats. }\end{array}$ & $\begin{array}{l}\downarrow \text { blood serum markers (AST, ALT, LDH, CK-MB, and CPK). } \\
\downarrow \text { lipid peroxidation levels (MDA). } \\
\uparrow \text { GSH. } \\
\uparrow \text { antioxidant enzymes (CAT, SOD, GPx, GR, and GST). } \\
\downarrow \text { inflammatory Cytokine (IL2). }\end{array}$ \\
\hline $\begin{array}{l}\text { Cyclophosphamide induced } \\
\text { cardiotoxicity [54] }\end{array}$ & Adult male albino wistar rats & $\begin{array}{l}50 \mathrm{mg} / \mathrm{L} \text { in drinking water (calculated } \\
\text { dose of TQ- } 4 \mathrm{mg} / \mathrm{kg} / \text { day) }\end{array}$ & $\begin{array}{l}\downarrow \text { CK-MB, LDH, Serum cholesterol, TG, urea, creatinine. } \\
\uparrow \text { ATP production. } \\
\downarrow \text { TBARS and NO(x). } \\
\uparrow \text { GSH, SOD, GPx, and CAT. } \\
\downarrow \text { proinflammatory mediator }(\mathrm{TNF}-\alpha) .\end{array}$ \\
\hline $\begin{array}{l}\text { Cisplatin induced } \\
\text { cardiotoxicity [55] }\end{array}$ & Adult male albino wistar rats & 40 mg/kg/day i.p & $\begin{array}{l}\text { Restored myocardial damage as observed by } \\
\text { histopathological changes. } \\
\uparrow \text { expression of Bcl-2(anti-apoptotic protein) in myocardial fibers, } \\
\text { indicating decreased apoptotic cardiomyocytes. }\end{array}$ \\
\hline $\begin{array}{l}\text { Tamoxifen induced } \\
\text { hepatotoxicity [56] }\end{array}$ & Adult female Sprague-Dawley rats & $50 \mathrm{mg} / \mathrm{kg}$, body weight p.o & $\begin{array}{l}\downarrow \text { serum enzymes of liver such as AST, ALT, } \gamma \text { GT, LDH and ALP and } \\
\text { total bilirubin. } \\
\downarrow \text { liver Lipid peroxidation level and TNF- } \alpha \text {. } \\
\uparrow \text { GSH, SOD. } \\
\text { Improved histopathological changes (edema of interstitial tissues and } \\
\text { inflammation with decreased size of von kuppfer cells). }\end{array}$ \\
\hline $\begin{array}{l}\text { Cisplatin induced } \\
\text { hepatotoxicity [57] }\end{array}$ & Male Albino wistar rats & $500 \mathrm{mg} / \mathrm{kg} /$ day p.o & $\begin{array}{l}\downarrow \text { serum hepatic biomarkers.(ALT, ALP, AST, } \gamma \text { GGT, TB, LDH and } \uparrow \\
\text { serum albumin levels). } \\
\uparrow \text { GSH-px, SOD, GST, GSH, CAT activities. } \\
\downarrow \text { MDA formation. } \\
\downarrow \text { iNOs, TNF } \alpha \text { and IL-1 } \beta, \text { NF-Kb-P65 activation. }\end{array}$ \\
\hline $\begin{array}{l}\text { Cyclophosphamide induced } \\
\text { toxicity [58] }\end{array}$ & Male Albino wistar rats & $10 \mathrm{mg} / \mathrm{kg}$, intragastric injection & $\begin{array}{l}\downarrow \text { AST, ALT, ALP, } \gamma \text {-GT and CPK levels. } \\
\downarrow \text { elevated levels of urea, creatinine and bilirubin. } \\
\downarrow \text { TG, cholesterol, and LDL levels. } \\
\uparrow \text { GSH and decreased MDA levels. }\end{array}$ \\
\hline
\end{tabular}


Table 2. Cont.

\begin{tabular}{|c|c|c|c|}
\hline Drug Induced Toxicity & Experimental Model & TQ Dose & Effect of TQ \\
\hline $\begin{array}{l}\text { Methotrexate induced } \\
\text { hepato-renal toxicity [59] }\end{array}$ & Adult male albino wistar rats & $10 \mathrm{mg} / \mathrm{kg} /$ day p.o & $\begin{array}{l}\text { Improved renal and hepatic biomarkers ( } \downarrow \text { elevated levels of BUN, } \\
\text { creatinine, ALT and AST). } \\
\uparrow \text { GSH, CAT. } \\
\downarrow \text { renal and hepatic MDA, NO, and TNF- } \alpha \text { levels. } \\
\downarrow \text { expression of iNOs in both kidney and liver. } \\
\text { Improved renal and hepatic histology } \\
\downarrow \text { NF- } \kappa \text { B, COX-2 and caspase } 3 \text { expressions in kidney and liver. }\end{array}$ \\
\hline $\begin{array}{l}\text { Doxorubicin induced } \\
\text { hyperlipidemic } \\
\text { nephropathy [60] }\end{array}$ & Male albino wistar rats & $10 \mathrm{mg} / \mathrm{kg} /$ day p.o & $\begin{array}{l}\downarrow \text { serum urea. } \\
\uparrow \text { serum proteins and albumin. } \\
\downarrow \text { Urinary protein, albumin and NAG excretions. } \\
\downarrow \text { TG and TC in blood and renal tissue. } \\
\downarrow \text { Renal TBARS levels } \uparrow \text { renal NPSH content and CAT activity. }\end{array}$ \\
\hline $\begin{array}{l}\text { Cisplatin induced } \\
\text { nephrotoxicity [61] }\end{array}$ & Swiss albino mice, Wistar albino rats & $\begin{array}{l}8 \mathrm{mg} / \mathrm{kg} / \text { day for mice, } \\
4 \mathrm{mg} / \mathrm{kg} / \text { day for rats p.o }\end{array}$ & $\begin{array}{l}\downarrow \text { serum urea, serum creatinine, and urine volume in both mice } \\
\text { and rats. } \\
\uparrow \text { creatinine clearance. } \\
\text { Improved histopathological changes in rats (less degenerative damage } \\
\text { and decreased loss of the tubular epithelium). }\end{array}$ \\
\hline $\begin{array}{l}\text { Doxorubicin induced } \\
\text { nephrotoxicity [62] }\end{array}$ & Male Sprague-Dawley rats & $50 \mathrm{mg} / \mathrm{kg} /$ day p.o & $\begin{array}{l}\downarrow \text { creatinine, BUN and albuminuria. } \\
\downarrow \text { lipid peroxidation in renal cells. } \\
\uparrow \text { SOD and GST. } \\
\text { Restored Nrf } 2 \text { mRNA and Nrf2 binding activity in kidney. } \\
\text { Attenuated renal NOX-4 levels. } \\
\downarrow \text { IL6 and TNF- } \alpha \text { and } \uparrow \text { IL-10. } \\
\text { Improved renal histopathology (almost normal renal tubules } \\
\text { and glomeruli). }\end{array}$ \\
\hline $\begin{array}{l}\text { Ifosfamide induced } \\
\text { nephrotoxicity [63] }\end{array}$ & Male wistar albino rats & $50 \mathrm{mg} / \mathrm{L}$ p.o & $\begin{array}{l}\downarrow \text { urea and creatinine levels in the blood. } \\
\uparrow \text { serum phosphate, albumin content and creatinine clearance. } \\
\downarrow \text { fractional and total excretion of sodium, potassium, phosphate, } \\
\text { glucose and organic acids. } \\
\uparrow \text { GSH, GST. } \\
\downarrow \text { Lipid peroxides. }\end{array}$ \\
\hline
\end{tabular}


Table 2. Cont.

\section{Drug Induced Toxicity}

Methotrexate induced

intestinal toxicity [64]
Experimental Model

TQ Dose

Effect of TQ

Improved intestinal histology (mild shortening of villi present).

$\uparrow$ intestinal GSH, CAT and $\downarrow$ MDA levels.

$\downarrow$ rise in total nitrite/nitrate levels and iNOS intestinal expression.

$\downarrow$ TNF- $\alpha$ and $\downarrow$ expression of NF-KB and COX-2 in rat intestine. Reversed the up regulation of caspase 3 .

$\downarrow$ MDA levels and $\uparrow \mathrm{GSH}$; total SH levels.

$\uparrow$ activities of SOD, GSH-Px, CAT, GST, GR and TR and in intestinal mucosa.

$\uparrow$ ALP, GGTase, LAP, sucrose and decreased ACPase activity.

Cisplatin induced intestinal

toxicity [65]

Adult male Wistar rats

$1.5 \mathrm{mg} / \mathrm{kg}$ body weight, p.o

Significantly altered glucose metabolism enzymes in the mucosa

homogenate $(\downarrow \mathrm{LDH}, \mathrm{HK}, \mathrm{ME}$ and increased MDH, G6Pase, FBPase,

G6PDH activity)

Preserved intestinal histopathology (protected against the damage caused by cisplatin on morphology of intestine)

TQ $(20 \mathrm{mg} / \mathrm{kg})$ showed complete protection of bladder tissues against inflammatory changes when compared with its low and medium dose. Reversed the Nrf2 suppression and most prominent Nrf2 protein

Cyclophosphamide induced hemorrhagic Cystitis [66]

Male Balb/c mice

5,10 and $20 \mathrm{mg} / \mathrm{kg}$, i.p

expression was seen in the group receiving $20 \mathrm{mg} / \mathrm{kg}$ of TQ.

$\downarrow$ TNF- $\alpha$, IL- $1 \beta$ and IL- 6 levels in a dose related manner.

$\downarrow$ MDA level and significantly $\uparrow$ GSH, SOD, CAT levels in bladder tissue homogenates.

\section{Cisplatin induced}

ototoxicity [67]

Female Sprague-Dawley rats

$40 \mathrm{mg} / \mathrm{kg} /$ day i.p

TQ treatment preserved DPOAE responses and ABR thresholds.

Methotrexate induced

testicular injury [68]

Male C57BL/6 mice

$10 \mathrm{mg} / \mathrm{kg} /$ day i.p

TAC values and myeloperoxidase activity.

Upon microscopic examination of testes, treatment with TQ revealed almost normal seminiferous tubule morphology

\section{Cyclophosphamide induced}

pulmonary toxicity [69]

$100 \mathrm{mg} / \mathrm{kg} /$ day, p.o. $\downarrow$ serum total protein, TNF-a, TBARS level and SOD activity. Improved histopathological changes (no intralobular necrosis or substantial inflammatory infiltration, indicating minimal lung damage.) 


\subsubsection{Protective Effect against Cardiotoxicity}

Many studies have demonstrated that $\mathrm{TQ}$ has a cardioprotective effect against chemotherapeutic drug-induced cardiotoxicity. Doxorubicin is an antitumor antibiotic used in the treatment of various types of cancer but its use is restricted due to the dose limiting cardiotoxicity. Alam et al. [23] conducted a study which demonstrated that serum enzyme markers of cardiotoxicity such as AST, ALT, CK-MB, and LDH in doxorubicin treated groups were elevated. MDA, a final product of lipid peroxidation, which act as an indicator for oxidative stress was increased and antioxidant enzymes such as CAT, SOD, GPx, GR, GST and GSH were decreased in doxorubicin treated groups. Oxidative stress occurs due to increase in reactive oxygen species generation and/or weakened antioxidant defense mechanism. Upon TQ treatment in mice $(10 \mathrm{mg} / \mathrm{kg}, 20 \mathrm{mg} / \mathrm{kg}$ p.o), elevated levels were restored to normal. They also suggested that restoration may be due to the high antioxidant property of thymoquinone in the myocardium, thus minimizing the damage to the cardiac muscle fibers caused by doxorubicin. Co-treatment with TQ also restored the elevated levels of inflammatory cytokine (IL2) in cardiac tissue. These results were in accordance with other studies on doxorubicin-induced cardiotoxicity [53,70,71]. Karabulut et al. [71] performed a histopathological examination which revealed myocardial fibril disorganization in DOX-treated groups which was almost normally organized after treatment with TQ (10 mg/kg i.p). ANP and NT-proBNP values were determined, revealing that a doxorubicin dose of $15 \mathrm{mg} / \mathrm{kg}$, i.p resulted in cardiac dysfunction leading to heart failure. These values were decreased by administration of thymoquinone before and after DOXtreatment. TQ supplementation also prevented cyclophosphamide-induced cardiotoxicity by restoring the abnormal levels of serum cardiac markers, lipid peroxidation, antioxidant enzymes and inflammatory mediators [54]. Cisplatin treatment caused myocardial tissue necrosis and apoptosis as evidenced by histopathological examination, which was diminished after TQ administration [55].

\subsubsection{Protective Effect against Hepatotoxicity}

Tamoxifen is commonly recommended for treatment of patients with breast cancer [72]. It has the unusual side effect of producing hepatotoxicity, making long-term use challenging. Treatment with tamoxifen to rats resulted in significant increase in ALT, ALP, AST, $\mathrm{LDH}, \gamma \mathrm{GT}$ and total bilirubin. Histopathological changes included swelling of interstitial tissues and inflammation of Von Kuppfer cells with atrophy. There was a significant increase in lipid peroxidation level, inflammatory marker (TNF- $\alpha$ ) and a significant decrease in antioxidant levels. All these changes ameliorated after administration of TQ [56]. It also showed hepatoprotective activity against cisplatin, cyclophosphamide and methotrexate toxicity with similar improvements in hepatic serum markers, lipid peroxidation, inflammatory markers, and antioxidant levels [57-59]. As a defence mechanism, inducible nitric oxide synthase (iNOs) is known to produce significant levels of nitric oxide; however, the excess production may cause damage to the liver. El-Sheikh et al. [59] performed immunohistochemical staining of the liver in methotrexate-treated rats and it was observed that iNOs expression upregulated, which confirmed nitrosative stress. Nitric oxide levels were also increased in cisplatin-induced hepatotoxicity [57]. These effects were reversed after treatment with TQ, suggesting that it has an antinitrosative effect. All these data show that TQ has hepatoprotective activity and can be used as an adjuvant in treating hepatotoxicity caused by chemotherapeutic drugs.

\subsubsection{Protective Effect against Nephrotoxicity}

Literature survey revealed the protective effect of thymoquinone against nephrotoxicity in rats when given in combination with doxorubicin, cisplatin and ifosfamide. Badary et al. [58] demonstrated that doxorubicin treatment produced renal changes as manifested by hypoproteinemia, proteinuria, albuminuria, hyperlipidemia, hypoalbuminemia. They also evaluated oxidative stress as examined by lipid peroxide generation, non-protein sulfhydryl (NPSH) concentration and catalase (CAT) activity in renal tissue. These changes 
were improved after TQ administration to nephritic rats. A study was conducted on both rats as well as mice by Badary et al. [59] revealing that the rats were more sensitive to cisplatin-induced nephrotoxicity than mice. It was found that serum urea and serum creatinine levels were elevated with decreased creatinine clearance, increased urinary volume and renal tubular damage was also observed in the cisplatin treated group. Similar changes were also observed in ifosfamide-induced nephrotoxicity [63]. Upon TQ administration, the abnormal levels were restored to normal. TQ showed protection against doxorubicininduced nephrotoxicity by improving lipid peroxidation, antioxidant levels, nitrosative stress markers as well as inflammatory markers [62].

\subsubsection{Protective Effect against Intestinal Toxicity}

Methotrexate is known to cause serious intestinal toxicity. A study has demonstrated the mechanism by which TQ shows protection against methotrexate-induced intestinal toxicity. It acts by decreasing oxidative and nitrosative stress markers in intestinal mucosa, decreasing expression of inflammatory markers (TNF- $\alpha, \mathrm{NF}-\mathrm{\kappa B}$ and COX-2) and by inhibiting apoptosis [64]. Another study by Shahid et al. [65] estimated the effect of long-term cisplatin use in rat intestines and the role of TQ in preventing toxicity. It was observed that repeated doses of cisplatin increased MDA levels, decreased GSH and TSH levels, as well as other antioxidant enzymes such as SOD, GSH-Px, CAT, GST, GR and TR in intestinal mucosa. Glutathione peroxidase, glutathione reductase, and glutathione-s-transferase are the main GSH-dependent antioxidant enzymes. Histopathology of brush border mucosa (BBM) revealed morphological changes such as congestion, swelling of villi, alteration in the contour and increased lymphocytic infiltration in the lamina propria associated with reduction in the crypt/villus ratio. It was further noticed that there was a significant reduction in enzyme markers of brush border mucosa which are sucrase, ALP, GGTase, and LAP. They also observed alterations in enzymes involved in carbohydrate metabolism. These abnormalities in both methotrexate and cisplatin were restored to normal upon TQ administration.

\subsubsection{Protective Effect against Urotoxicity}

Cyclophosphamide-induced hemorrhagic cystitis is the dose limiting toxicity causing damage to urothelium of bladder mucosa. However, administration of TQ has shown protective activity against it by increasing antioxidant enzymes, decreasing lipid peroxidation, reducing levels of inflammatory markers, and maintaining the structure and morphology of the urinary bladder by increasing Nrf2 expression. Oxidative stress causes the level of Nrf2 to decrease [66].

\subsubsection{Protective Effect against Ototoxicity}

Sagit et al. [65] demonstrated that cisplatin-induced ototoxicity in rats is caused due to an increase in ABR thresholds and a decrease in DPOAE responses. The intensity of sound at which a brain response initially appears is determined by ABR analysis [73]. DPOAEs are emission of sounds in response to two tons of different frequencies played at the same time [74]. Accumulation of cisplatin in cochlear tissues generates excessive free radicals and decreases antioxidant enzymes which results in cochlear injury or cell death. TQ administration preserved the changes produced by cisplatin treatment [67].

\subsubsection{Protective Effect against Testicular Injury}

Gokce et al. [68] identified rise in TAC level and myeloperoxidase activity in methotrexate treated groups. An increase in TAC is a result of compensation to oxidative stress generated while increased myeloperoxidase activity indicates neutrophil accumulation leading to oxidative testicular damage. The seminiferous epithelium was severely disrupted, reducing the diameter of the seminiferous tubules and affecting the spermatogenetic cell lines. It also caused interstitial space dilation and edema in mice with cell size reduction and 
cytoplasmic swelling. TQ exerted its protective effect by restoring the abnormalities caused produced by methotrexate treatment.

\subsubsection{Protective Effect against Pulmonary Toxicity}

A study was conducted by Suddek et al. [69] to demonstrate acute pulmonary toxicity induced by cyclophosphamide. They observed increase in MDA levels, SOD (as a compensatory mechanism), total protein, serum LDH, TNF- $\alpha$ and a decrease in GSH. Histopathological examination of the lung revealed congestion, damage, swelling of interalveolar septum, neutrophilic, and macrophages infiltration. TQ supplementation resulted in reversal of the changes produced by Cyclophosphamide.

\section{Role of Thymoquinone against Chemotherapy Induced Oxidative Stress}

Reactive oxygen species (ROS) are produced as a result of various cellular processes involving endogenous and exogenous pathways, constituting oxidative stress [75]. Endogenous pathways include oxidative phosphorylation, bacterial invasion, and inflammation; whereas exogenous pathway includes xenobiotics, radiation, and pollution. ROS are implicated in the anticancer mechanism of chemotherapy which further causes adverse effects. In other words, it has been established that chemotherapeutic agents have the potential to induce oxidative stress during the treatment [76]. Conklin [77] reported that among anticancer drugs, oxidative stress was observed to be the highest in theanthracycline class of drugs followed by platinum compounds, alkylating agents, epipodophyllotoxins and camptothecins but was lower in taxanes, antimetabolites, and vinca alkaloids. Hence the generation of ROS following the administration of chemotherapeutic agents decreases their efficacy. Inorder to prevent the side effects and to enhance responsiveness to therapy, antioxidants are recommended. SOD and CAT are antioxidant enzymes which are primarily responsible for destroying reactive oxygen metabolites. Glutathione enzymes (GSH, GPx, GR, GST) have an important role in providing secondary defense against oxidative damage caused by the generation of ROS [78]. Previous studies (refer Table 2) described how the supplementation of thymoquinone to experimental animals treated with chemotherapeutic agents increased antioxidant enzyme activity and thus showed some protection against organ damage.

\section{New Trends and Directions of Research Related to TQ}

Due to poor pharmacokinetic characteristics of TQ, its use in humans is limited as it is rapidly eliminated and slowly absorbed. To enhance bioavailability, several researchers developed nanoformulations of TQ which showed marked improvement in pharmacokinetic properties. In 2017, the United States government registered a clinical trial which evaluated the chemopreventive effect of TQ on oral potentially malignant lesions. Currently there are three completed trials and two ongoing trials registered for thymoquinone [79].However, there are no registered clinical trials on role of thymoquinone in reducing the toxicity of anticancer drugs. There are sufficient in vitro and in vivo studies describing the potential of $\mathrm{TQ}$ in reducing chemotherapeutic drug-induced toxicity, hence undertaking future clinical investigation in this particular area would be interesting in order to improve the efficacy of chemotherapy by diminishing the adverse effects produced during treatment.

\section{Conclusions}

TQ's influence on cancer, metabolic syndrome, drug-induced toxicity in general, antioxidant, anti-inflammatory, immunomodulatory, antibacterial activity, and many other topics has been discussed in previous review publications. This is the first study to look at the effect of TQ on anti-cancer drug-induced toxicity. As a result, we emphasize that TQ has excellent organoprotective properties and might be utilized in conjunction with chemotherapy to minimize toxicity. The studies above show that TQ protects against the side effects of some of the most regularly used chemotherapy drugs. However, more 
research on diverse types of chemotherapeutic drugs is needed to have a better knowledge of their protective effects on several other physiological parameters.

Author Contributions: J.F., T.T., H.S., M.I., S.A. and R.T. conceptualized and wrote initial draft of the manuscript. A.J.A., M.A.M., M.A.A.H. and M.K. participated in data curation and literature search. The review and final editing of the manuscript was carried out by S.M.B.A. and R.S. The supervision of the manuscript writing was performed by R.S. All authors have read and agreed to the published version of the manuscript.

Funding: This review article was funded by AlMaarefa University, Riyadh, Saudi Arabia.

Acknowledgments: The authors are thankful to Yenepoya deemed to be University for providing support to do this review. The author MK is thankful to the Deanship of Scientific Research at Prince Sattam Bin Abdulaziz University, Al-Kharj, Kingdom of Saudi Arabia for providing support.

Conflicts of Interest: The authors declare no conflict of interest.

\section{Abbreviation}

ABR Auditory brainstem response

ALT Alanine aminotransferase

ANP Atrial natriuretic peptide

AST Aspartate aminotransferase

ATP Adenosine triphosphate

BUN Blood urea nitrogen

CAT Catalase

CK-MB Creatine kinase myocardial band

CPK Creatine phosphokinase

DOX Doxorubicin

DPOE Distortion product otoacoustic emissions

FBPase Fructose 1.6-bisphosphatase

G6Pase Glucose 6-phosphatase

G6PDH Glucose 6-phosphate dehydrogenase

GGTase $\gamma$-Glutamyl transferase

GPx Glutathione peroxidase

GR Glutathione reductase

GSH Reduced glutathione

GST Glutathione S-transferease

HK Hexokinase

IL-2 Interleukin-2

IL-6 Interleukin-6

IL-10 Interleukin-10

IL-18 Interleukin-18

iNOs Inducible nitric oxide synthase

I.P Intraperitoneally

LAP Leucine aminopeptidase

LDH Lactate dehydrogenase

MDA Malondialdehyde

$\mathrm{MDH} \quad$ Malate dehydrogenase

ME Malic enzyme

NAG $\quad N$-acetyl-b-D-glucosaminidase

$\mathrm{NO}(\mathrm{x}) \quad$ Total nitrate/nitrite

NPSH Non-protein sulfhydryl

Nrf2 Nuclear factor erythroid 2-related factor 2

P.O Per os

ProBNP Pro-B type natriuretic peptide

SH Sulfhydryl 


$\begin{array}{ll}\text { SOD } & \text { Superoxide dismutase } \\ \text { TAC } & \text { Total antioxidant capacity } \\ \text { TAS } & \text { Tissue anti-oxidant status } \\ \text { TC } & \text { Total cholesterol } \\ \text { TG } & \text { Triglycerides } \\ \text { TOS } & \text { Tissue oxidant status } \\ \text { TQ } & \text { Thymoquinone } \\ \text { TR } & \text { Thioredoxin reductase }\end{array}$

\section{References}

1. Available online: https://www.cancer.gov/about-cancer/understanding/what-is-cancer\#definition (accessed on 13 April 2021).

2. Available online: http://www.healthdata.org/results/gbd_summaries/2019/total-cancers-level-2-cause (accessed on 24 April 2021).

3. Indian Council of Medical Research; Public Health Foundation of India; Institute for Health Metrics and Evaluation. GBD India Compare Data Visualization. New Delhi: ICMR, PHFI, and IHME. 2017. Available online: http://vizhub.healthdata.org/gbdcompare/india (accessed on 5 April 2021).

4. Wu, S.; Zhu, W.; Thompson, P.; Hannun, Y.A. Evaluating intrinsic and non-intrinsic cancer risk factors. Nat Commun. 2018, 9 , 3490. [CrossRef] [PubMed]

5. Cleeland, C.S. Cancer-related symptoms. In Seminars in Radiation Oncology; WB Saunders: Philadelphia, PA, USA, 2000; Volume 10, pp. 175-190. Available online: https:/ / www.who.int/news-room/fact-sheets/detail/cancer (accessed on 10 May 2021).

6. Katzke, V.A.; Kaaks, R.; Kühn, T. Lifestyle and cancer risk. Cancer J. 2015, 21, 104-110. [CrossRef]

7. Wagner, E.; Elliot, K.; Enders, W.; Chobanuk, J.; Tsui, A. BOOK REVIEW: Chemotherapy and Biotherapy Guidelines. Can. Oncol. Nurs. J. Rev. Cancer Soins Infirm. Oncol. 2015, 25, 480.

8. Tarver, T. Cancer Facts E Figures 2012; American Cancer Society(ACS): Atlanta, GA, USA, 2012; p. 66.

9. Brenner, G.M.; Stevens, C.W. Antineoplastic Drugs, Text Book of Pharmacology, 3rd ed.; Saunders Elsevier: Philadelphia, PA, USA, 2010; pp. 493-511.

10. Rang, H.P.; Dale, M.M.; Ritter, J.M. Anticancer Drugs, Text Book of Pharmacology, 7th ed.; Elsevier: Amsterdam, The Netherlands, 2012; pp. 673-687.

11. Remesh, A. Toxicities of anticancer drugs and its management. Int. J. Basic Clin. Pharmacol. 2012, 1, 2-12. [CrossRef]

12. Fennell, C.W.; Lindsey, K.L.; McGaw, L.J.; Sparg, S.G.; Stafford, G.I.; Elgorashi, E.E.; Grace, O.M.; VanStaden, J. Assessing African medicinal plants for efficacy and safety: Pharmacological screening and toxicology. J. Ethnopharmacol. 2004, 94, 205-217. [CrossRef]

13. Doughari, J.H.; Human, I.S.; Bennade, S.; Ndakidemi, P.A. Phytochemicals as chemotherapeutic agents and antioxidants: Possible solution to the control of antibiotic resistant verocytotoxin producing bacteria. J. Med. Plant Res. 2009, 3, 839-848.

14. Doughari, J.H.; Obidah, J.S. Antibacterial potentials of stem bark extracts of Leptadenia lancifoli against some pathogenic bacteria. Pharmacologyonline 2008, 3, 172-180.

15. Rao, V. (Ed.) Phytochemicals: A Global Perspective of Their Role in Nutrition and Health; BoD-Books on Demand; Intechopen: London, UK, 2012.

16. Singh, S.; Jarial, R.; Kanwar, S.S. Therapeutic effect of herbal medicines on obesity: Herbal pancreatic lipase inhibitors. Wudpecker J. Med. Plants 2013, 2, 53-65.

17. Rahman, M.; Beg, S.; Verma, A.; Al Abbasi, F.A.; Anwar, F.; Saini, S.; Akhter, S.; Kumar, V. Phytoconstituents as pharmacotherapeutics in rheumatoid arthritis: Challenges and scope of nano/submicromedicine in its effective delivery. J. Pharm. Pharmacol. 2017, 69, 1-14. [CrossRef] [PubMed]

18. Chan, J.Y.Y.; Yuen, A.C.Y.; Chan, R.Y.K.; Chan, S.W. A review of the cardiovascular benefits and antioxidant properties of allicin. Phyther Res. 2013, 27, 637-646. [CrossRef]

19. Davinelli, S.; Sapere, N.; Zella, D.; Bracale, R.; Intrieri, M.; Scapagnini, G. Pleiotropic protective effects of phytochemicals in Alzheimer's disease. Oxid Med Cell Longev. 2012, 2012, 386527. [CrossRef]

20. Sak, K. Site-specific anticancer effects of dietary flavonoid quercetin. Nutr. Cancer 2014, 66, 177-193. [CrossRef] [PubMed]

21. Ogle, W.O.; Speisman, R.B.; Ormerod, B.K. Potential of treating age-related depression and cognitive decline with nutraceutical approaches: A mini-review. Gerontology 2012, 59, 23-31. [CrossRef] [PubMed]

22. Williams, D.J.; Edwards, D.; Hamernig, I.; Jian, L.; James, A.P.; Johnson, S.K.; Tapsell, L.C. Vegetables containing phytochemicals with potential anti-obesity properties: A review. Food Res. Int. 2013, 52, 323-333. [CrossRef]

23. Alam, M.F.; Khan, G.; Safhi, M.M.; Alshahrani, S.; Siddiqui, R.; Sivagurunathan, M.S.; Anwer, T. Thymoquinone ameliorates doxorubicin-induced cardiotoxicity in swiss albino mice by modulating oxidative damage and cellular inflammation. Cardiol. Res. Pract. 2018, 2018, 1483041. [CrossRef]

24. Aras, S.; Gerin, F.; Aydin, B.; Ustunsoy, S.; Sener, U.; Turan, B.C.; Armutcu, F. Effects of sodium arsenite on the some laboratory signs and therapeutic role of thymoquinone in the rats. Eur. Rev. Med. Pharmacol. Sci. 2015, 19, 658-663. 
25. Alrashedi, M.G. The Protective Role of Thymoquinone against Drugs Toxicity: A Review. J. Pharm. Res. Int. 2018, $24,1-11$. [CrossRef]

26. Available online: https://commons.wikimedia.org/wiki/File:Nigella_sativa_002.JPG (accessed on 20 November 2021).

27. Melissa, P. “black cumin”. Encyclopedia Britannica. 2018. Available online: https://www.britannica.com/plant/black-cumin (accessed on 18 November 2021).

28. Taborsky, J.; Kunt, M.; Kloucek, P.; Lachman, J.; Zeleny, V.; Kokoska, L. Identification of potential sources of thymoquinone and related compounds in Asteraceae, Cupressaceae, Lamiaceae, and Ranunculaceae families. Cent. Eur. J. Chem. 2012, 10, 1899-1906. [CrossRef]

29. Darakhshan, S.; Pour, A.B.; Colagar, A.H.; Sisakhtnezhad, S. Thymoquinone and its therapeutic potentials. Pharmacol. Res. 2015, 95, 138-158. [CrossRef]

30. Abukhader, M.M. The effect of route of administration in thymoquinone toxicity in male and female rats. Indian J. Pharm. Sci. 2012, 74, 195-200. [CrossRef]

31. Taha, M.M.; Sheikh, B.Y.; Salim, L.Z.; Mohan, S.; Khan, A.; Kamalidehghan, B.; Ahmadipour, F.; Abdelwahab, S.I. Thymoquinone induces apoptosis and increase ROS in ovarian cancer cell line. Cell Mol. Biol. 2016, 62, 97-101.

32. Wilson, A.J.; Saskowski, J.; Barham, W.; Yull, F.; Khabele, D. Thymoquinone enhances cisplatin-response through direct tu-mor effects in a syngeneic mouse model of ovarian cancer. J. Ovarian Res. 2015, 8, 46. [CrossRef]

33. Yıldırım, I.H.; Azzawri, A.A.; Duran, T. Thymoquinone induces apoptosis via targeting the Bax/BAD and Bcl-2 pathway in breast cancer cells. Dicle Tip Derg. 2019, 46, 411-417. [CrossRef]

34. Rajput, S.; Kumar, B.N.; Dey, K.K.; Pal, I.; Parekh, A.; Mandal, M. Molecular targeting of Akt by thymoquinone promotes $\mathrm{G}(1)$ arrest through translation inhibition of cyclin D1 and induces apoptosis in breast cancer cells. Life Sci. 2013, 93, 783-790. [CrossRef] [PubMed]

35. Relles, D.; Chipitsyna, G.I.; Gong, Q.; Yeo, C.J.; Arafat, H.A. Thymoquinone promotes pancreatic cancer cell death and reduction of tumor size through combined inhibition of histone deacetylation and induction of histone acetylation. Adv. Prev. Med. 2016, 2016, 341. [CrossRef]

36. Samarghandian, S.; Azimi-Nezhad, M.; Farkhondeh, T. Thymoquinone-induced antitumor and apoptosis in human lung adenocarcinoma cells. Journal of cellular physiology. J. Cell Physiol. 2019, 234, 10421-10431. [CrossRef]

37. Hussein, S.A.; Abdel-Aal, S.A.; Amin, A.; Khalaf, H.A. Caspase-3, Bcl-2, p53, CYP1A1 and COX-2 as a potential target in chemoprevention of Benzo (a) pyrene-induced lung carcinogenesis in mice: Role of thymoquinone. Nat. Sci. 2016, 4, $430-441$.

38. Badary, O.A.; Gamal El-Din, A.M. Inhibitory effects of thymoquinone against 20-methylcholanthrene-induced fibrosarcomatumorigenesis. Cancer Detect Prev. 2001, 25, 362-368.

39. Arumugam, P.; Subramanian, R.; Priyadharsini, J.V.; Gopalswamy, J. Thymoquinone inhibits the migration of mouse neuroblastoma (Neuro-2a) cells by down-regulating MMP-2 and MMP-9. Chin. J. Nat. Med. 2016, 14, 904-912. [CrossRef]

40. Peng, L.; Liu, A.; Shen, Y.; Xu, H.; Yang, S.; Ying, X.; Shen, W. Antitumor and anti-angiogenesis effects of thymoquinone on osteosarcoma through the NF-kB pathway. Oncol. Rep. 2013, 29, 571-578. [CrossRef]

41. Siveen, K.S.; Mustafa, N.; Li, F.; Kannaiyan, R.; Ahn, K.S.; Kumar, A.P.; Chng, W.J.; Sethi, G. Thymoquinone overcomes chemoresistance and enhances the anticancer effects of bortezomib through abrogation of NF- $\mathrm{kB}$ regulated gene products in multiple myeloma xenograft mouse model. Oncotarget 2013, 5, 634-648. [CrossRef]

42. Abdelfadil, E.; Cheng, Y.H.; Bau, D.T.; Ting, W.J.; Chen, L.M.; Hsu, H.H.; Lin, Y.M.; Chen, R.J.; Tsai, F.J.; Tsai, C.H.; et al. Thymoquinone induces apoptosis in oral cancer cells through p38 $\beta$ inhibition. Am. J. Chin. Med. 2013, 41, 683-696. [CrossRef] [PubMed]

43. Kundu, J.; Choi, B.Y.; Jeong, C.H.; Kundu, J.K.; Chun, K.S. Thymoquinone induces apoptosis in human colon cancer HCT116 cells through inactivation of STAT3 by blocking JAK2- and Src mediated phosphorylation of EGF receptor tyrosine kinase. Oncol. Rep. 2014, 32, 821-828. [CrossRef] [PubMed]

44. Chen, M.C.; Lee, N.H.; Hsu, H.H.; Ho, T.J.; Tu, C.C.; Hsieh, D.J.Y.; Lin, Y.M.; Chen, L.M.; Kuo, W.W.; Huang, C.Y. Thymoquinone Induces Caspase-Independent, Autophagic Cell Death in CPT-11- Resistant LoVo Colon Cancer via Mitochondrial Dysfunction and Activation of JNK and p38. J. Agric. Food Chem. 2015, 63, 1540-1546. [CrossRef] [PubMed]

45. Singh, S.K.; Apata, T.; Gordetsky, J.B.; Singh, R. Docetaxel Combined with Thymoquinone Induces Apoptosis in Prostate Cancer Cells via Inhibition of the PI3K/AKT Signaling Pathway. Cancers 2019, 11, 1390. [CrossRef]

46. Das, S.; Dey, K.K.; Dey, G.; Pal, I.; Majumder, A.; Choudhury, S.M.; Kundu, S.C.; Mandal, M. Antineoplastic and apoptotic potential of traditional medicines thymoquinone and diosgeninin squamous cell carcinoma. PLoS ONE 2012, 7, e46641. [CrossRef] [PubMed]

47. Feng, L.M.; Wang, X.F.; Huang, Q.X. Thymoquinone induces cytotoxicity and reprogramming of EMT ingastric cancer cells by targeting PI3K/Akt/mTOR pathway. J. Biosci. 2017, 42, 547-554. [CrossRef]

48. Musalli, M.G.; Hassan, M.A.; Sheikh, R.A.; Kalantan, A.A.; Halwani, M.A.; Zeyadi, M.; Hosawi, S.; Alhosin, M. Thymoquinone induces cell proliferation inhibition and apoptosis in acute myeloid leukemia cells: Role of apoptosis-related WT1 and BCL2 genes. Eur. J. Cell Sci. 2019, 1, 2-9. [CrossRef]

49. Butt, A.S.; Nisar, N.; Ghani, N.; Altaf, I.; Mughal, T.A. Isolation of thymoquinone from Nigella sativa L. and Thymus vulgaris L., and its anti-proliferative effect on HeLa cancer cell lines. Trop. J. Pharm. Res. 2019, 18, 37-42. [CrossRef] 
50. Meral, I.; Pala, M.; Akbas, F.; Ustunova, S.; Yildiz, C.; Demirel, M. Effects of thymoquinone on liver miRNAs and oxidative stress in Ehrlich acid mouse solid tumor model. Biotech. Histochem. 2018, 93, 301-308. [CrossRef]

51. Bashir, A.O.; El-Mesery, M.E.; Anwar, R.; Eissa, L.A. Thymoquinone potentiates miR-16 and miR-375 expressions in hepato-cellular carcinoma. Life Sci. 2020, 254, 117794. [CrossRef] [PubMed]

52. Park, J.E.; Kim, D.-H.; Ha, E.; Choi, S.M.; Choi, J.-S.; Chun, K.S.; Joo, S.H. Thymoquinone induces apoptosis of human epi-dermoid carcinoma A431 cells through ROS-mediated suppression of STAT3. Chem. Biol. Interact. 2019, 312, 108799. [CrossRef] [PubMed]

53. Nagi, M.N.; Mansour, M.A. Protective effect of thymoquinone against doxorubicin-induced cardiotoxicity in rats: A possible mechanism of protection. Pharmacol. Res. 2000, 41, 283-289. [CrossRef] [PubMed]

54. Nagi, M.N.; Al-Shabanah, O.A.; Hafez, M.M.; SayedAhmed, M.M. Thymoquinone supplementation attenuates cyclophosphamideinduced cardiotoxicity in rats. J. Biochem. Mol. Toxicol. 2011, 25, 135-142. [CrossRef]

55. Adalı, F.; Gonul, Y.; Kocak, A.; Yuksel, Y.; Ozkececi, G.; Ozdemir, C.; Tunay, K.; Bozkurt, M.F.; Sen, O.G. Effects of thymoquinone against cisplatin-induced cardiac injury in rats. Acta Cir. Bras. 2016, 4, 271-277. [CrossRef]

56. Suddek, G.M. Protective role of thymoquinone against liver damage induced by tamoxifen in female rats. Can. J. Physiol. Pharmacol. 2014, 92, 640-644. [CrossRef]

57. Al-Malki, A.L.; Sayed, A.A. Thymoquinone attenuates cisplatin-induced hepatotoxicity via nuclear factor kappa- $\beta$. BMC Complement. Altern. Med. 2014, 14, 282. [CrossRef]

58. Alenzi, F.Q.; El-Bolkiny, Y.E.; Salem, M.L. Protective effects of Nigella sativa oil and thymoquinone against toxicity induced by the anticancer drug cyclophosphamide. Br. J. Biomed. Sci. 2010, 67, 20-28. [CrossRef]

59. El-Sheikh, A.A.; Morsy, M.A.; Abdalla, A.M.; Hamouda, A.H.; Alhaider, I.A. Mechanisms of thymoquinone hepatorenal protection in methotrexate-induced toxicity in rats. Mediat. Inflamm. 2015, 2015, 859383. [CrossRef]

60. Badary, O.A.; Abdel-Naim, A.B.; Abdel-Wahab, M.H.; Hamada, F.M. The influence of thymoquinone on doxorubicin-induced hyperlipidemic nephropathy in rats. Toxicology 2000, 143, 219-226. [CrossRef]

61. Badary, O.A.; Nagi, M.N.; Al-Shabanah, O.A.; Al-Sawaf, H.A.; Al-Sohaibani, M.O.; Al-Bekairi, A.M. Thymoquinone ameliorates the nephrotoxicity induced by cisplatin in rodents and potentiates its antitumor activity. Can. J. Physiol. Pharmacol. 1997, 75, 1356-1361. [CrossRef] [PubMed]

62. Elsherbiny, N.M.; El-Sherbiny, M. Thymoquinone attenuates Doxorubicin-inuced nephrotoxicity in rats: Role of Nrf2 and NOX4. Chem. Biol. Interact. 2014, 223, 102-108. [CrossRef] [PubMed]

63. Badary, O.A. Thymoquinone attenuates ifosfamide-induced Fanconi syndrome in rats and enhances its antitumor activity in mice. J. Ethnopharmacol. 1999, 67, 135-142. [CrossRef]

64. El-Sheik, A.A.; Morsy, M.A.; Hamouda, A.H. Protective mechanisms of thymoquinone on methotrexate-induced intestinal toxicity in rats. Pharmacogn. Mag. 2016, 12, 76-81.

65. Shahid, F.; Farooqui, Z.; Khan, A.A.; Khan, F. Oral Nigella sativa oil and thymoquinone administration ameliorates the effect of long-term cisplatin treatment on the enzymes of carbohydrate metabolism, brush border membrane and antioxidant defense in rat intestine. Naunyn Schmiedebergs Arch. Pharmacol. 2018, 391, 145-157. [CrossRef] [PubMed]

66. Gore, P.R.; Prajapati, C.P.; Mahajan, U.B.; Goyal, S.N.; Belemkar, S.; Ojha, S.; Patil, C.R. Protective effect of thymoquinone against cyclophosphamide-induced hemorrhagic cystitis through inhibiting DNA damage and upregulation of Nrf2 expression. Int. J. Biol. Sci. 2016, 12, 944. [CrossRef] [PubMed]

67. Sagit, M.; Korkmaz, F.; Akcadag, A.; Somdas, M.A. Protective effect of thymoquinone against cisplatin-induced ototoxicity. Eur. Arch. Oto-Rhino-Laryngol. 2013, 270, 2231-2237. [CrossRef] [PubMed]

68. Gökçe, A.; Oktar, S.; Koc, A.; Yonden, Z. Protective effects of thymoquinone against methotrexate-induced testicular injury. Hum. Exp. Toxicol. 2011, 30, 897-903. [CrossRef] [PubMed]

69. Suddek, G.M.; Ashry, N.A.; Gameil, N.M. Thymoquinone attenuates cyclophosphamide-induced pulmonary injury in rats. Inflammopharmacology 2013, 21, 427-435. [CrossRef] [PubMed]

70. Pehlivan, D.Y.; Durdağı, G. Effects of Thymoquinone on Blood Parameters in Doxorubicin Cardiotoxicity. Exp. Appl. Med. Sci. 2020, 1, 7-16.

71. Karabulut, D.; Ozturk, E.; Kaymak, E.; Akin, A.T.; Yakan, B. Thymoquinone attenuates doxorubicin-cardiotoxicity in rats. J. Biochem. Mol. Toxicol. 2021, 35, e22618. [CrossRef]

72. Dunn, B.K.; Wickerham, D.L.; Ford, L.G. Prevention of hormone-related cancers: Breast cancer. J. Clin. Oncol. 2005, 23, 357-367. [CrossRef] [PubMed]

73. Bogaerts, S.; Clements, J.D.; Sullivan, J.M.; Oleskevich, S. Automated threshold detection for auditory brainstem responses: Comparison with visual estimation in a stem cell transplantation study. BMC Neurosci. 2009, 10, 104. [CrossRef]

74. Kirby, B.J.; Kopun, J.G.; Tan, H.; Neely, S.T.; Gorga, M.P. Do “optimal” conditions improve distortion product otoacoustic emission test performance? Ear Hear. 2011, 32, 230. [CrossRef]

75. Ray, P.D.; Huang, B.; Tsuji, Y. Reactive oxygen species (ROS) homeostasis and redox regulation in cellular signaling. Cell Signal. 2012, 24, 981-990. [CrossRef]

76. Kasapovi, J.; Stojiljkovi, V.; Todorovi, A.; Rado, L.; Sai, Z.S.; Pajovi, B. Antioxidant status and lipid peroxidation in the blood of breast cancer patients of different ages after chemotherapy with 5- fluorouracil, doxorubicin and cyclophosphamide. Clin Biochem. 2010, 43, 1287-1293. [CrossRef] [PubMed] 
77. Conklin, K.A. Chemotherapy-associated oxidative stress: Impact on chemotherapeutic effectiveness. Integr. Cancer Ther. 2004, 3, 294-300. [CrossRef] [PubMed]

78. Prabasheela, B.; Singh, A.K.; Fathima, A.; Pragulbh, K.; Deka, N.J.; Kumar, R. RRST-Health Science Association between Antioxidant Enzymes and Breast Cancer. Recent Res. Sci. Technol. 2014, 3, 93-95.

79. Available online: https:/ / clinicaltrials.gov/ct2/results?term=thymoquinone (accessed on 20 November 2021). 